\title{
Az Országos Református Nőszövetség indulásának körülményei (1943-1944)
}

1943-1944-ben a református egyház vezetősége szembenézve a történelmi helyzettel, a nők erejében bízva, rájuk támaszkodva, egy nőszövetségi mozgalmat ${ }^{1}$ indított, melynek célja az volt, hogy felkészítse az egyház társadalmi bázisát az elkerülhetetlen változásokra. Élére két olyan női vezetőt jelölt ki Zsindelyné Tüdős Klára és Pilder Mária személyében, akik hitelesen közvetítették a Magyar Református Egyház (MRE) céljait, és népszerüségüknél fogva képesek voltak a legkülönbözőbb társadalmi rétegekhez tartozó református nőket megszólítani.

A tanulmányban nőtörténeti szempontból közelítem meg az egyháztörténet e fejezetének feltárását. Az egyháztörténet-írók ugyanúgy, mint a hagyományos történetírást művelők, évszázadokon keresztül férfiak voltak, és a nők történetére az egyházban kevésbé fordítottak figyelmet. Napjainkban a történettudomány egyik virágzó területe a történelem genderszemléletű feltárása lett, melyben élen járnak a nőtörténészek, és a sajátos női szemlélet érvényesítésével, új források és módszerek felhasználásával újszerü módon világítják meg a történelem egyes epizódjait. ${ }^{2}$ A református felekezethez tartozó nők történetére is ráirányult a figyelem mind a hazai történetírásban, mind az egyháztörténetben. ${ }^{3}$ A szerző az MRE történetének egy nőtörténeti szempontból is releváns szeletét, az 1943-ban létrehozott Országos Református Nőszövetség (ORN) indulásának körülményeit kívánja bemutatni a Nőszövetség 1944-ben (szeptembertől decemberig, havonta egy alkalommal) megjelent lapjának, az Ujj Magyar Asszony című periodikának a segítségével. A nőtörténeti és női megközelítésü egyháztörténeti írás sajtótörténeti elemzés is egyben, hiszen a Nőszövetség sajtóorgánumának kulturális-társadalmi kontextusát ${ }^{4}$ megragadó, társadalomtörténeti vizsgálatát nyújtja.

A legfőbb kutatói kérdések, melyekre kerestem a választ, a következők voltak: milyen céllal indították el az MRE vezetői e női mozgalmat, kiket, milyen társadalmi réteghez tartozó reformátusokat kívántak elérni és ehhez milyen eszközöket tudtak felhasználni? A Nőszövetség Új Magyar Asszony címü lapjának induló számaiban e fenti törekvések hogyan tükröződtek? Milyen főbb tematikában jelentek meg írások, kik írták a cikkeket, milyen volt a nők és a férfiak aránya a szerzők között? Kik voltak azok a nők, akik az egyes rovatokat vezették? Milyen életpályát jártak be? Milyen felekezeti és társadalmi hátterük volt? Hogyan élték meg a lap keletkezésének idején zajló történelmi eseményeket? A válaszokat az Országos Református Nőszövetség elnökének, Zsindelyné Tüdős Klárának életútjára és kapcsolati hálójára fókuszálva találtam meg. Igyekeztem feltárni a lap szerzői gárdájának kapcsolódását az MRE-hez, illetve a Nőszövetség vezetőihez. Kiemeltem a rovatvezető női szerzők - Zsindelyné Tüdős Klára, Pilder Mária, Ignácz Rózsa - életrajzának

1 Országos Református Nőszövetség (továbbiakban Nőszövetség) elnevezéssel.

2 Czeferner 2020; Kéri 2013; Kéri 2013; Papp - Sipos 2017; Pálmai 2012.

3 Géra 2006; Kósa 2006; Rébay 2009; Rébay 2011; Rébay 2019; Sárai 2002; Sárai 2009; Sárai 2011; SÁRAI 2014.

4 GYÁNI 2006. 
azon elemeit, amelyek hatással lehettek cikkeik tartalmára. A kérdések megválaszolásához életrajzi adatokat, visszaemlékezéseket, korabeli sajtóterméket, filmhíradórészletet elemeztem a forráskritika módszerét alkalmazva.

\section{Az Országos Református Nőszövetség megalakulása}

Az Országos Református Nőszövetség tevékenységét és létrejöttének célját tekintve illeszkedett a 19. század végétől induló református belmissziói és ébredési ${ }^{5}$ mozgalmak folyamatába. E nőszövetséget nem egyesületként, az egyháztól elkülönülő, önálló szervezetként jegyezték be, hanem mint nőmozgalmat indította el Ravasz László (1882$1975)^{6}$ több egyházi vezetővel, Muraközy Gyulával (1892-1961), ${ }^{7}$ Bereczky Alberttel (1893-1966), ${ }^{8}$ és Makkai Sándorral (1890-1951) együtt 1943 végén. A mozgalmi jelleget a püspök azért preferálta, mert a célja az volt, hogy integrálja az egyház szervezetébe az egyházi ébredés önálló egyesületeit, amelyeknek számos konfliktusai voltak a gyülekezeti alapon szerveződő egyházzal. ${ }^{10} \mathrm{E}$ törekvés már 1938-ban elkezdődött, ${ }^{11}$ s számos, korábban létesített, református kötődésű egyesület olvadt be a Dunamelléki Református Egyházkerület által kezdeményezett Nőszövetség gyülekezeti szinten szerveződött tagozataiba. ${ }^{12}$ A szerveződés ezen formái azonban nem voltak elég hatékonyak. Egyre nagyobb szükség lett a református nőket összefogó olyan mozgalomra, amelynek nem „a nöegyesületekben szokványos jótékonyság az elsödleges feladata, hanem a gyülekezetekben a hitbuzgalmi, missziói tevékenység" 13 fokozása. Az Új Magyar Asszony első számának vezércikkében Zsindelyné Tüdős Klára kihangsúlyozta, hogy „a Magyar Református Nöszövetség nem egy "Nöegylet « a sok közül, hanem a gyülekezet minden Krisztust keresö nötagjának szövetsége." ${ }^{14}$ Makkai Sándor írásában szintén utalt arra, hogy az

\footnotetext{
5 A belmisszió a 19. században a liberális teológia racionalizmusa ellen lépett fel Nyugat-Európa nagyvárosainak protestáns egyházi közösségeiben, s a különféle ébredési mozgalmak, mint a pietizmus vagy a puritanizmus táplálta. Célja a laicizálódási folyamat megállítása volt; az 1930-as évek közepéig a protestáns felekezetekhez kötődő egyesületekben folyt. Magyarországon az első ébredési mozgalom az 1860-as években Debrecenben indult el, és a puritán örökségű, új ortodoxiára épült. Képviselői Balogh Ferenc és Csiky Lajos voltak (KIss 2006; Ács 2015).

6 Ravasz László (1882-1975): a Dunamelléki Református Egyházkerület püspöke (1921-1948), az MRE Konventjének (1937-1949) és Zsinatának lelkészi elnöke (1938-1948).

7 Muraközy Gyula (1892-1961): református lelkész, szerkesztő, író, műfordító. Az Egyetemes Konvent Missziói előadója.

8 Bereczky Albert (1893-1966): a lap keletkezésekor a Budapest-Pozsonyi úti Református Egyházközség lelkipásztora.

9 Makkai Sándor (1890-1951): erdélyi püspök (1926-1936), debreceni teológiai tanár, a Református Nószövetség címü teológiai értekezése lett az újonnan alakult mozgalom munkatervének az alapja (KósA 2006. 746.).

10 KIss 2006.

11 MakKai 1938; Ács 2015.

12 Az 1923-ban Nyáry Pálné kezdeményezésére alakult Pécsi Református Nők Regnum Christianum Egyesülete 1942-ben beolvad a „dunamelléki egyházkerület által megszervezni rendelt Pécsi Református Egyházközségi Nöszövetségbe és e végett kimondja feloszlatását.” BREL B. 12. c. 8699/1944. A. sz. irat. A Pécsi Református Nők Regnum Christianum Egyesületének feloszlatását és vagyonának hovafordítását kimondó közgyủlési határozat. 1944. november 14.

13 Kósa 2006. 745-746.

14 Zsındelyné Tüdős Klára: Asszonyok, ti ne féljetek! Új Magyar Asszony 1. (1944):1. 2.
} 
egyesület feloszlatható, de a szövetség Krisztusban örök. ${ }^{15}$ Az MRE vezetősége hitte, hogy a belső megújulást segítő evangelizációban olyan erő lakozik, mely a lelkekben megfoganva a túlélést jelentheti az MRE számára az új korszak beköszöntével. Ravasz László két ismert asszonyra kívánta bízni a négy magyarországi református egyházkerület közös Református Nőszövetsége vezetői feladatainak ellátását. A püspök elnöknek a kor ismert politikusának, Zsindely Ferencnek ${ }^{16}$ feleségét, a népszerü jelmeztervezőt, divattervezőt, rendezőnőt, a Budapest-Pozsonyi úti Református Egyházközség tagját, Tüdős Klárát; titkárnak pedig Pilder Máriát, az Erdélyi Református Nőszövetség sikeres szervezőjét és híres igemagyarázót, Karl Barth ${ }^{17}$ tanítványát kérte fel. Zsindelyné Tüdős Klára így emlékezik meg az elnökké választásáról: „Nekem fogalmam sem volt róla, hogy mi a tennivalóm, mikor elövezettek a Konventen a püspökök, püspöknék és számos egyhäzi föhatóságok elé, akikröl sejtelmem sem volt, hogy kik. Közölték velem, hogy országos elnöke vagyok valaminek, amiröl azt sem tudtam, eszik-e vagy isszák?" 18

1944-ben az Országos Református Nőszövetség megjelentette munkatervét, melyet Ravasz László és Zsindelyné Tüdős Klára szerkesztett, s melynek előszavában Ravasz László arra bíztatta a Bibliai Márták és Máriák seregét, hogy „egy világszerte folyó nagyszabású munka magyarországi barázdájába kell beállnia a magyar asszonyoknak és leányoknak." ${ }^{19} \mathrm{~A}$ történelemi események azonban gátat vetettek a Nőszövetség munkájának: 1944. március 19-én a német hadsereg megszállta az országot, emiatt az Országos Református Nőszövetség 1944. április 30-ára tervezett alakuló gyűlését nem tudták összehívni. „Csendes nagygyülést" ${ }^{20}$ tartottak helyette, azaz az ott elhangzott programbeszédeket körlevelekben juttatták el a gyülekezetek számára. „Ahogy a dörgés, villámlás, vagyis a front közeledett az országhoz, megbolydultak az emberek és menekültek ide-oda. 1944 nyarától decemberéig különös fergetegbe keveredett a Nöszövetség éppen hogy elültetett csenevész fácskája." ${ }^{21}$ emlékezett vissza Tüdős Klára e nehéz időkre. 1945 decemberéig nem volt tisztújítás, nem történt meg a Nőszövetség tényleges megalakulása sem. A történelmi idők azonban kijelölték a feladatokat, s e rendkívüli szervezőkészséggel megáldott asszony felismerte ezek megoldásában a Nőszövetség és benne a saját szerepét; asszonyokat, munkatársakat toborzott a gyülekezetekben, hogy teát fözzenek a menekülteknek, vasúti mosdóhelyeket tisztíttatott ki, ahová vaskályhát állíttatott, hogy rajta mosdóvizet melegítsenek a napok óta fürösztetlen csecsemőknek. Zsindelyné Tüdős Klára és segítői összegyüjtötték a pályaudvaron egyedül maradt kicsinyeket, öregeket, elesetteket, s Zsindelyék Istenhegyi úton lévő otthonában szállást, élelmet biztosítottak számukra. Segítségére volt ebben a szeretetszolgálatban két tanítónő: M. Kovács Piroska, aki a Fasori Református Leányott-

\footnotetext{
15 MaKKaI Sándor: Mi a Református Nőszövetség? Új Magyar Asszony 1. (1944):1. 5-6.

16 Zsindely Ferenc (1891-1963): 1938-ban vallás- és közoktatásügyi miniszteri államtitkár, 1939-ben Teleki Pál kormányában miniszterelnökségi államtitkár, 1944. március 22-ig kereskedelem- és közlekedésügyi miniszter volt a Kállay-kormányban.

17 Karl Barth (1886-1968): svájci protestáns teológus. A nemzeti szocialista eszme ellen fellépő Hitvalló Egyház mozgalom alapítója 1935-ben.

18 Zsindelyné 1998. 24.

19 RaVASZ - ZsindeLYNÉ 1944. 10.

20 DiZseri 1994. 184.

21 ZsINDELYNÉ 1998. 32.
} 
hon vezetője volt, ${ }^{22}$ Juhász Ilonka, aki a Soli Deo Gloria Diákszövetség utazó titkáraként tevékenykedett, valamint Cserepes Ella. M. Kovács Piroska segítette Zsindelyné Tüdős Klárát a Nőszövetség Új Magyar Asszony címủ lapja körüli tevékenységekben is. Szálasi Ferenc hatalomra kerülését követően a fővárosban felgyorsult a zsidóság deportálása, és egyre nagyobb méreteket öltöttek a politikai okok miatti bebörtönzések. E nehéz helyzetben Zsindelyné összefogva a Filadelfia Szövetség diakonisszáival és Asta Nielsennel, ${ }^{23}$ a svéd nagykövetség munkatársával, mentették a zsidókat. ${ }^{24}$ Somogyi Imre ${ }^{25}$ ajánlotta Zsindelyné pártfogásába a papírok nélkül érkező kommunista üldözötteket. ${ }^{26}$ Tették mindezt a Svábhegy tetején, a Gestapo közelségében, felülemelkedve a napi és a jövőre vonatkozó egzisztenciális félelmeiken, Jézus igéjének engedelmeskedve: „Aki egyet befogad az én kicsinyeim közül, engem fogad be.” ${ }^{27}$ Félelmeik pedig voltak: „Kicsit megremegtem a gondolattól, hogy nem a magam, hanem az uram nyakát reszkirozom azzal, ha illegalitásban lévö embereket befogadok." ${ }^{28}$ - írja visszaemlékezésében Zsindelyné. A feleség aggódott férjének jelenéért és jövőbeli sorsáért, hiszen Zsindely Ferenc egy jobboldali, de angolbarát, keresztyén, igen magas beosztású horthysta politikus volt, aki 1944. március 22-én, miután a német csapatok megszállták az országot, lemondott a Kállay-kormányban betöltött kereskedelem- és közlekedésügyi miniszteri tisztségéről, s elvesztette korábbi politikai befolyását. A távolabbi jövő a Vörös Hadsereg által felszabadított új Magyarországon szintén szorongásra adhatott okot a házaspárnak. Mindennapi félelmeik is gyötrőek voltak: lesz-e elegendő tüzelö, élelem, szappan az időnként 80 fôt is meghaladó vendégeknek? Hogyan védik meg az orosz katonák erőszakoskodásaitól a lányokat és az asszonyokat? A legnehezebb időkben álltak helyt segítőikkel együtt: emberfeletti küzdelemben próbáltak otthonukban emberhez méltó életet teremteni az üldözötteknek, védve hol a németek, hol az orosz katonák erőszakos kegyetlenkedései elől a náluk meghúzódó kiszolgáltatottakat. Ennek az időszaknak a tapasztalatai alapul szolgáltak (erkölcsi értelemben is) Zsindelyné Tüdős Klárának ahhoz a munkához, amit a társaival együtt 1949-ig végzett a Nőszövetség élén.

1944 második felének embert próbáló, életet veszélyeztető időszakában volt erejük a Nőszövetség újságjának megalapítására és megjelentetésére. Tüdős Klára ötlete volt, hogy a Református Nőszövetség céljainak eléréséhez lapot kell indítani, s

${ }^{22}$ Később Bottyán János, az Új Magyar Asszony szerkesztőjének a felesége lett. OHATI NAGY László: Somogyi Imre. Valóság 26. (1983):1. 68.

23 Asta Nielsen (1881-1972): dán színésznő, a némafilm első európai sztárjának számított. (BALÁzs Géza: Asta Nielsen. Fényszóró 1. (1945):10. 10-11. 1944-ben a svéd Vöröskereszt budapesti megbízottja és a svéd nagykövetség titkárnője volt. A nagykövetség tagjai „1944 karácsony estéjét a pesti gettóban töltötték és csak pár nap múlva a nuncius közbenjárására szabadultak ki." Svéd bástya a nyilas áradatban. Hogyan harcoltak a budapesti svéd követség tagjai a nyilas pártszolgálatosokkal. Demokrácia 5. (1946): 10. 7.

24 2001-ben a Világ Igaza díjjal tüntették ki. DÉsI János: „Aki egy embert megment, az egész világot menti meg." Népszava, 2001. december 3.

25 Somogyi Imre (1902-1947) szobrász, a Parasztpárt alapítója, a kertmozgalom szószólója, a német megszállást követően az ellenállási mozgalom tagja lett. Györffy István munkatársa, Zsindelyné barátja, aki ösztönözte arra, hogy a fôvárosban tanuló, falusi származású, szegény sorsú főiskolások részére kollégiumot létesítsenek (Dizseri 1994. 141.). Többek között ennek hatására is jött létre a Györffy István Kollégium. 1945 után az Ideiglenes Nemzetgyủlés tagja volt. 1947-ben orosz katonák lőtték meg a Hősök terén, mert nem engedelmeskedett, nem vetkőzött le a parancsukra. Sérülésébe belehalt.

26 Itt élték át az ostromot Szakasits Árpádnak és Apró Antalnak a családtagjai is. Dizseri 1994. 165-169.

27 Zsindelyné 1998. 38-39.

28 ZsINDELYNÉ 1998. 38. 
Balla Péter ${ }^{29}$ segítségével meggyőzte Bottyán Jánost ${ }^{30}$ a szerkesztői feladatok elvégzésére, melynek eredményeként 1944. szeptember 15-én megjelent a Nőszövetség szócsöveként az Új Magyar Asszony első száma.

\section{Az Új Magyar Asszony címü lap}

Az eddig írt tanulmányok és sajtóbibliográfia szerint 1944-ben két lapszámmal jelentkezett az Új Magyar Asszony, ${ }^{31}$ de a Kecskeméti Református Egyházközség Könyvtára és Levéltára négyet őriz 1944-ből, ezek a példányok szolgálnak az elemzés tárgyául. ${ }^{32} 1945$ ben nem jelentették meg az újságot. 1946 januárjában indult újra körlevélként az Országos Református Nőszövetség kiadványa, s havi rendszerességgel jelentkezett. A harmadik évfolyam 1947-től hitbuzgalmi havilapként látott napvilágot májusig, havonta egy alkalommal, majd júniustól kéthetente, 1948 végéig. Jelenleg a periodika ötödik évfolyamából két januári példányról tudunk. ${ }^{33} \mathrm{Az} U$ Uj Magyar Asszony kiadója az Országos Református Nőszövetség volt, a lapot a Sylvester Nyomdában nyomtatták. 1947 végéig Bottyán János, 1948 áprilisától 1948 decemberéig Áprily Lajos, 1949-ben Adorján József szerkesztette. ${ }^{34}$

\section{A lap címe, mottója és illusztrációja}

Az Új Magyar Asszony címet választották a lap elindítói ennek az újságnak, mely társadalmi bázisát tekintve szélesebb kört célzott meg, mint általában a református sajtóorgánumok. Zsindelyné úgy fogalmazott az induló lapszám vezércikkében, hogy az új magyar asszony „korának szenvedö, de bátor, józan leánya, aki egyetlen törvényéül és eröforrásául a Bibliát vállalja és egy kaszthoz, a magyar református asszonyok közösségéhez tartozónak vallja magát." ${ }^{35}$ A szerkesztők az evangéliumi közösséget tartották meghatározónak és nem a társadalmit: nem a középosztálynak kívántak lapot szerkeszteni, hanem a népnek. Céljukat a lap mottója fejezte ki igazán: „Egyenként megállni a viharban lehetetlen, tájékoztatás nélkül élni badarság, kötés nélkül széthull a kéve." ${ }^{6}$ A mottó az 1850-ben írt Tompa Mihály $A$

\footnotetext{
29 Balla Péter (1908-1984): 1944-ben a református Soli Deo Gloria Diákszövetség országos énekügyi titkára volt.

30 Dr. Bottyán János (1911-1984): református lelkész, a Református Egyház című lapnak és a Confessiónak a felelős szerkesztője, a Budapesti Teológiai Akadémia díszdoktora, egyházmegyei tanácsbíró. Vö. ZsL 80. Zsinati Levéltár 80. fond. Bottyán János adattára.

31 Dizseri 1994. 212-215.; CseH - MÉsZÁros 2006. 1295.

32 Az első lapszám 1944. szeptember 15-én jelent meg Budapesten, majd ezt követően minden hónap 15-én jelent meg a periodika 1944. december 15-ig. Vö. A Kecskeméti Református Egyházközség Könyvtára és Levéltára elektronikus katalógusa. (http://krekbib.hu/k\%C3\%B6nyvt\%C3\%A1r/foly\%C3\%B3iratok/\%C3\%BAjmagyar-asszony) [2021.02.14.] Köszönet illeti Bán Magdolnát, az intézmény vezetőjét és munkatársait, akik a COVID-19 idején azzal segítették e tanulmány megszületését, hogy elektronikus formában rendelkezésre bocsátották e lapszámokat.

33 Dizseri 1994. 215. A Krekbib és az OSZK katalógusai szerint. A periodika megjelenési körülményeiről további kutatások szükségesek.

34 DeZsénYi et al. 1956.

35 Zsındelyné Tüdős Klára: Asszonyok, Ti ne féljetek! Új Magyar Asszony 1. (1944):1. 1.

36 Uj Magyar Asszony 1. (1944): 2-4.
} 
gólyához című versét idézi: „Mint oldott kéve széthull nemzetünk” ${ }^{37}$ Az Új Magyar Asszony címủ lap mottójaként a reformátusságnak a magyarsággal való azonosítását konnotálja, megteremtve a két történelmi kontextus, az 1848-49-es szabadságharc bukása és a Horthy-korszak vége közötti párhuzamot. A 19. század költőjének sorai - „Sokra sirr, sokra vak börtön borul, / Kik élünk: járunk búsan, szótlanul; / Van, aki felkél és sirván, megyen / Uj hont keresni túl a tengeren." 38 - Zsindelyné barátainak, ismerőseinek döntését vetíti elénk, többek között Darányi Kálmánnéét, aki mielőtt elhagyta az országot, tudván, hogy Klára asszony menekült otthonokat szervez a nőszövetségi asszonyokkal, átadta lakása kulcsát azokkal a szavakkal, melyekre Zsindelyné így emlékezett vissza: „használjam a házat, amire jónak látom." ${ }^{39}$ A mottó egyben kijelölte az újság s egyben a Nőszövetség szerepét a nemzet és a reformátusság sorsában: a kötés biztosítását.

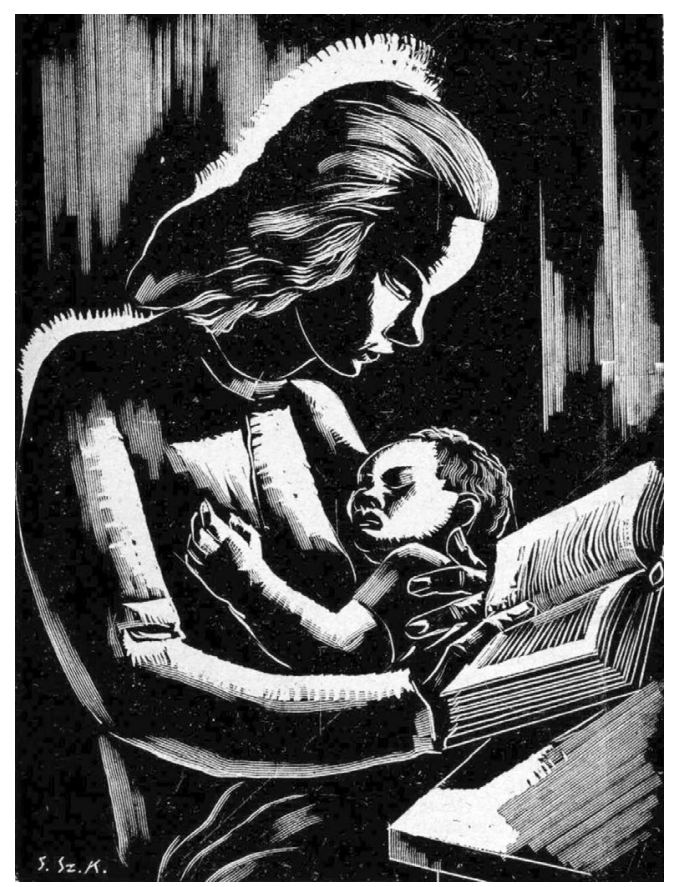

1. kép - Gáborjáni Szabó Kálmán

fametszete, a lap egyetlen illusztrációja

Több számában az első oldalon jelent meg Gáborjáni Szabó Kálmán fametszete mint a lap egyetlen illusztrációja. A kép fénytől megvilágított, alvó csecsemőt a kezében tartó, olvasó édesanyát ábrázol. (1. kép) Az alakok elhelyezkedése, valamint a megvilágított édesanya kapcsán a Mária Jézussal jelenetre asszociálhatunk. Az ábrázolás üzenete felerősítette a nők szerepére vonatkozó egyházi álláspontot, mely elsősorban a középosztályhoz tartozó nők társadalmi szerepvállalásai kapcsán a két világháború között

\footnotetext{
${ }_{37}$ TомрA (https://www.arcanum.hu/hu/online-kiadvanyok/Verstar-verstar-otven-kolto-osszes-verse-2/ tompa-mihaly-9406/lirai-koltemenyek-940B/1850-98A3/a-golyahoz-98D0/) [2021.03.23.]

${ }_{38}$ Томра (https://www.arcanum.hu/hu/online-kiadvanyok/Verstar-verstar-otven-kolto-osszes-verse-2/ tompa-mihaly-9406/lirai-koltemenyek-940B/1850-98A3/a-golyahoz-98D0/) [2021.03.23.]

39 Dizseri 1994. 163.
} 
a liberális feminizmus ellenében fogalmazódott meg: az egyház nem utasította el a nők művelődéséhez, tanulásához, munkához való jogát, ha az a család, az egyház és a haza szolgálatában állt. Ignácz Rózsa írónő négy cikkben is foglalkozott a nők olvasóvá nevelésével. (Melléklet 1. táblázat)

\section{A szerkesztő és a szerzői gárda 1944-ben}

A Dunántúli Protestáns Lap Új Magyar Asszonyt népszerűsítő írásában arról számolt be, hogy „olyan munkatársi gárdát választottak, amely a kitüzött nagy célnak mindenben megfelel. Az ország legjobbjai teszik közkinccsé a lapban tudásuk legjavát. Szerkesztöül Bottyán Jánost, a Református Jövö ismert szerkesztöjét és munkatársát kérték fel." 40

A vezércikkek írói között találjuk Ravasz Lászlót, Makkai Sándort és egyetlen nőként, Zsindelyné Tüdős Klárát. (Melléklet 1. táblázat) A vezércikkeket bibliai textuson alapuló, személyes hangvételű, meggyőző írások kísérték, melyek - a püspök és lelkipásztorai - Ravasz László, Bottyán János, Péter János, Békési Andor tollából születtek. A periodika munkatársai közül többen képviselték a női nemet, mindegyikük személyes ismerőse, barátja, segítője, munkatársa volt Zsindelyné Tüdős Klárának. Pilder Mária, a Nőszövetség országos titkára, Ignácz Rózsa írónő, M. Kovács Piroska, aki Istenhegyen a menekültek ellátásában is segítségére volt és Tóth Erika, a Tiszántúli Egyházkerület Református Nőszövetségének képviselőnője nevükkel jelentek meg a lapokban: Zsindelyné 5, Pilder Mária 5, Ignácz Rózsa 3, M. Kovács Piroska és Tóth Erika 1-1 cikkel, Berde Mária Amália ${ }^{41}$ egy verssel szerepeltek. Szécsi Árpádnét ${ }^{42}$ és Bertalan Esztert jelölték még meg az első, illetve a második lap munkatársai között, de sajnos nem derült ki, mely cikknek voltak ők a szerzői vagy milyen más szerepük volt az újság létrehozásában. A névvel megjelent írások közül 15-öt hölgyek és 35-öt férfiak írtak (a szépirodalmi művekkel együtt).

\section{A női cikkírók életpályája}

Az Új Magyar Asszony cikkíró hölgyei mindannyian reformátusok voltak. Zsindelyné Tüdős Klára a kálvinista Rómában, Debrecenben született 1885-ben, mindkét ágon híres református prédikátor ősökkel. A Dóczy Gedeon vezette Debreceni Református Leánynevelő Intézetben tanult 1905-től 1911-ig. Így emlékezett vissza az iskolapadban töltött évekre: „a reggeli áhitatokon buzdításomra úgy énekeltük a zsoltárt: ásitozik testem, lelkem, s miután a konfirmációi órák egybeestek a táncóráimmal, lehetöleg mellöztem a konfirmációi elökészitést." ${ }^{33}$ A megtérése sokkal később történt, életútjának felén, édesanyja betegágyánál, Bereczky Albert lelkipásztor hatására. „Amig beszélt, nekem elkezdett csorogni lefelé a könnyem, s a szivem úgy emelkedett Hozzá, mintha szárnya nött volna. (...) És aztán soha többé nem hiányoztam a pozsonyi útról, amig ö azon a szószéken állt" ${ }^{44}$ - írta

\footnotetext{
40 Pongrácz József: Új Magyar Asszony. Dunántúli Protestáns Lap 55. (1944):38. 1.

41 Berde Mária (1889-1949): erdélyi költő, író. Édesapja református lelkész, a Nagyenyedi Bethlen Kollégium tanára. RMIL Berde Mária. (https://lexikon.kriterion.ro/szavak/340/) [2021.02.19.]

42 Szécsi Árpádné Zsindelyné Tüdős Klára munkatársa volt a Corvin Áruházban. Dizseri 1994.

43 ZsINDELYNÉ 1998. 9.

44 ZsINDELYNÉ 1998. 19.
} 
a visszaemlékezésében. A Nőszövetség munkájába való bekapcsolódásáig egy izgalmas, nem mindennapi, a korszakban modern jelzővel illethető független, önálló, dolgozó nő életútja bontakozik ki előttünk. Az 1910-es években országgyűlési képviselő apja egyedüli gyermekeként gondtalan, jómódú életet élt: Svájcban, Angliában tanult francia és angol nyelvet. 1915-ben Lembergben önkéntes ápolónőként a háborúban megsebesült katonákat ápolt. Budapesten tanulmányokat folytatott az Iparművészeti Főiskola textil szakán. 1919-ben férjhez ment Szunyogh Rudolf huszárfőhadnagyhoz, s az érmelléki Érsemjénre költözött, ahol a 400 holdas Szunyogh-birtokot irányította, mert férje a háborúból súlyos tüdőbetegen tért vissza, $s$ különböző szanatóriumokban gyógyíttatta magát. A házaspárnak 1921-ben kislánya született, Judit. Trianon után „román határörcsaládok vérszemet kaptak, hogy nincs otthon a gazda, s kezdtek a birtokon garázdálkodni. Hol a termésböl kanyaritottak ki egy darabot, hol a terelt állatokat tizedelték meg." ${ }^{45}$ Egy napon leégett a birtokon az összes cselédlakás, s ekkor gyermekével visszaköltözött Magyarországra. Férjével elhidegültek egymástól, évekig külön éltek, majd 1928-ban elváltak. Kislányukat jó ideig Tüdős Klára nagynénje nevelte Debrecenben. 1925-ben Budapestre került és önálló karriert épített. Elöször a Magyar Állami Operaházban a női jelmeztár és szabászműhely vezetője volt. Jelmeztervezőként, rendezőként és fordítóként sikereket ért el, melyekről egyre nagyobb rendszerességgel tudósított a sajtó. ${ }^{46}$ 1927-től, tíz éven keresztül a Magyar Rádióban divatról szóló műsorokat vezetett. Divattervezőként elkötelezettje és vezéralakja volt a „magyaros ruhamozgalomnak”. ${ }^{47}$ „Magyar ruha az, amelyiknek, hogy úgy mondjam, az alaprajza magyar. És magyaros ruha, amelyiknek az alaprajza mondén. Mindkettönek megvan a maga létjogosultsága, tere és szereplési lehetösége. A magyar ruha nemzeti ügy, szinvallástétel és bizonyságtétel' 48 - hallhatjuk ma is a filmhíradó archív felvételéről Zsindely Ferencné Tüdős Klárát a magyaros divat lényegéről. 1937-ben megnyitotta a Pántlika Divatszalont, ${ }^{49}$ 1941-1943 között a Corvin Áruház vezetője lett, de a posztról le kellett mondania férje kereskedelmi miniszteri pozíciója miatt. 1938-ban ment feleségül Zsindely Ferenchez, aki akkor a Nemzeti Egység Pártja alelnöke, a Vallás- és Közoktatásügyi Minisztérium államtitkára, a Teleki-, a Bárdossy- és a Kállay-kormányok idején miniszterelnökségi államtitkár, majd a Kállay-kormányban kereskedelem- és közlekedésügyi miniszter volt. ${ }^{50}$ Zsindely Ferenc szintén a református felekezethez tartozott, jó viszonyt ápolt Ravasz László püspökkel. Hóman Bálint 1938 elején a protestáns ügyek államtitkárának nevezte ki. ${ }^{51}$ Tüdős Klára férje oldalán reprezentációs feladatokat látott el: jótékony célú divatbemutatókat szervezett, segítette férje politikai törekvéseit érvényre

\footnotetext{
45 Dizseri 1994. 54. Idézi: TüDős Klára: Rongyok I. Kiadatlan. 37.

46 Ifj. Ambrózy Ágoston: Gratulálunk a méltóságos asszonynak! Szinházi Magazin, 1939. október 14. 42.; Somfay Margit: Magyaros ünnepi ruhák. Élet, 1938. március 13. 475-476.; Budapesten született a „höndörgö” ötlete. Magyarország, 1937. június 10. 9.; A „Pántlika” igazán csak most virágozni - mondja Zsindely Ferencné, Tüdős Klára. Új Magyarság, 1938. augusztus 7. 7.; Magyar ruha. Muskátli - Magyar Kézimunkaújság 7. (1938):1. 1.

47 F. Dózsa 1998.

48 Magyaros divat. Zsindely Ferencné, Tüdős Klára előadása az Országos Iparművészeti Társulat női ruhabemutatóján. MFI: Nagy L., Zsabka, Marton. (https://filmhiradokonline.hu/watch.php?id=3489) [2021.02.16.]

49 Bagyinszky 2011. 61.

50 Dizseri 1994. 15.

51 Dizseri 1994. 88.
} 
jutni. Tehetségét és eltökéltségét bizonyítja, hogy 1943-ban filmrendezőként is megállta a helyét, s a Fény és Árnyék című filmjével nagy sikert aratott. Ravasz László az Országos Református Nőszövetség élére Zsindelyné Tüdős Klárában egy közismert és köztiszteletben álló személyt választott, egy igazi pártfogót, fáradhatatlan szervezőt, aki bár kezdetben megrémült a feladattól, de felismerte e mozgalom jelentőségét, és az átmenet éveiben kitartóan szolgálta annak céljait.

Pilder Mária (1855-1966) Diósgyőrött született, római katolikusnak keresztelték. Felnőtt korában áttért a református felekezetbe. 1918-ban édesanyja halála után édesapja szülőföldjére, Erdélybe költözött. Kolozsvárott teológiai tanulmányokat folytatott. Levelezett a svájci vallásos szocializmus harcos teológusával, Hermann Kutterrel, majd Karl Barth követője lett. ${ }^{52}$ 1920-tól Kolozsvárott egy leány-középiskolában, 1923-tól Nagyenyeden a Református Tanítóképző Intézetben tanított és annak internátusát igazgatta. ${ }^{53}$ Az Erdélyi Református Egyházkerület női belmissziói munkáinak felügyelője, utazótitkára és diakonissza intézetének vezetője volt. Újságírói és szerkesztői tapasztalatot is szerzett, mert Maksay Alberttel együtt szerkesztette a Református Család című havilapot. Zsindelyné emlékirataiban így emlékezett vissza a Pilder Máriával való első találkozásukra: „Különös kis teremtés volt ez a Mária, akiröl én semmit sem tudtam, mikor egy délután Muraközy Gyula felhozta hozzám a Sváb-hegyre. Kicsi, filigrán, idös hölgy, felemás arccal és rossz szemmel, megnyerönek nem mondható külsövel. (...) Féltem töle, s nem értettem, hogy mit kezdjek én egy öreg kisasszonnyal. Mint késöbb kiderült, ö is nagyon félt tölem, hogy viszont mit kezdjen ö egy nagyvilági dámával egyházi munkában. Én a kézfogásra intenziven reagálok, s ahogy mi akkor Máriával kezet fogtunk, bennem a görcs feloldódott, s tudtam, hogy ez egy életre szól". ${ }^{54}$ A Pilder Máriával való közös tevékenységük a Nőszövetség élén ténylegesen 1945 decemberének végén kezdődött el, s 1949 elejéig tartott. Az MRE vezetői, Bereczky Albert püspök, Kiss Roland egyházkerületi főgondnok és Farkas József miszsziói előadó személyesen meglátogatták Zsindelyné Tüdős Klárát istenhegyi otthonában, és ott Bereczky Albert a következő indokkal győzte meg Klára asszonyt, hogy adja át a Nőszövetség vezetését Szegedy Erzsébet diakonisszának: „Vezetö köreinkben és a pártban az a vélemény, hogy maga ugyanazt az államellenes propagandát csinálja az országban, amit a hercegprimás, Mindszenty? 55 - emlékezett vissza a naplójában Zsindelyné Tüdős Klára. A házaspár 1949. június 3-án szerződést kötöttek az egyházkerülettel, melyben átadták az Istenhegyen lévő házukat a Dunamelléki Református Egyházkerületnek „kizárólagos használatra missziói célokra (...) férfi és nöszövetségi vezetö és munkásképzö tanfolyamok tartására, egyházi munkás és lelkésznyaraltatásokra, konferenciákra". ${ }^{56}$

Az Új Magyar Asszony első évfolyamának női szerzői között több cikkel ott találjuk Ignácz Rózsa (1909-1979) színészt és írót. Erdélyben született, 14 évvel volt fiatalabb Zsindelyné Tüdős Kláránál. Édesapja Ignácz László, református lelkészként, majd később

\footnotetext{
52 ZsL 88. Pilder Mária iratai 1884-1956; valamint MÉL: Pilder Mária. (https://www.arcanum.hu/en/onlinekiadvanyok/Lexikonok-magyar-eletrajzi-lexikon-7428D/p-77238/pilder-maria-774BF/) [2021.02. 16.]

53 ZsL 88. Pilder Mária iratai 1884-1956; valamint MÉL: Pilder Mária. (Valószínűleg a Kolozsvári Református Leány-fógimnáziumban kapott állást. Ennek igazolása további kutatásokat igényel.)

54 Dizseri 1994. 184.

55 Dizseri 1994. 218.

56 DizSERI 1994. 221.
} 
esperesként szolgált Fogarason, magyar iskolát, a hadirokkantaknak segélyszervezetet alapított és árvaházat müködtetett. Ignácz Rózsa Kolozsvárott végezte a középiskolát, de szenvedett a Trianon utáni, románosított erdélyi iskolában, ahol kicsúfolták és megszégyenítették az anyanyelve miatt. Édesapja halála után édesanyjával és testvérével Magyarországra költöztek. Budapesten a Színiakadémián szerzett diplomát, Szegeden, majd Budapesten a Nemzeti Színházban kapott szerepeket. Unokatestvérével, a politikus és újságíró Makkai Jánossal kötött házasságot, s 1935-ben egy fiuk született, Ádám. Később elváltak, és a fiát egyedül nevelte fel. 1939-1940-ben a Szinházi Magazin párizsi tudósítójaként dolgozott. ${ }^{57}$ Közben színdarabokat, regényeket írt, ${ }^{58}$ és íróként egyre sikeresebb lett. 1942ben a Ferenc József-díj elnyerése után a vele készített interjúban olvashatjuk vallomását hivatásáról: „Nem készültem én soha sem írónak, sem szinésznek, hanem mindig csak Ignácz Rózsa akartam lenni. (...) Inkább élni szeretnék sokszor, mint irni." ${ }^{99} 1942$-ben a Pécsi Naplóban Pusztai-Popovits Józsefnek így mesélte el életének egy kalandos epizódját: „Megszereztem egy román nö igazolványát és azzal zavartalanul járkálhattam. Néha-néha a csendörök és rendörök igazoltattak, de amikor felmutattam a román igazolványt tovább engedtek. Úgyszólván házról-házra jártam a csángóknál és mintha román lennék úgy érdeklödtem életük és sorsuk iránt. A legnagyobb öszinteséggel beszéltek elöttem úgy a csángó magyarok, mint azok a csángók, akiket a románoknak már sikerült teljesen elrománositani az egyházon keresztül." 60 1944 őszén az írónő által átélt eseményekről a fia visszaemlékezéseiből tudunk. Ignácz Rózsa megszervezte volt férje esküvőjét egy amerikai származású hölggyel, Betty Smith-szel a rabkórházban. ${ }^{61}$ Makkai János a német megszállás után börtönbe került, mintegy 350 politikai fogollyal együtt, köztük Tildy Zoltánnal, Bajcsy-Zsilinszky Endrével, Nagy Ferenccel és Laky Dezsővel. „Egy német SS tábori pap adta össze őket ott, a Fö utcai rabkórházban, miközben Ignácz Rózsa és Mickó néni, Bajcsy-Zsilinszky Endréné-Bandi bácsi influenzát kapott - voltak a házassági tanúk. Én ezen alkalommal nem lehettem jelen, de anyám elöadásából elevenen többször is átéltem. Mikor kimentünk az utcára hazafelé indulva, anyám kivett egy zsidóknak járó sárga csillagot a retiküljéböl és azt a kabátja bal kihajtójára biggyesztette egy öreg rozsdás sicherheits tüvel." ${ }^{2}$ - írta Makkai Ádám. A fiú visszaemlékezéseiből egy szeretetteljes, de nem hagyományos, anya-gyermek kapcsolat bontakozik ki. Íme: „Koraérett, szemtelen és erösen elkapatott kölyök voltam, akinek "aranyköpéseiböl anyám cikkeket és "gyermekszáj krokikat« irt, ahelyett, hogy fözött volna rám, vagy sétálni vitt volna."63

57 SÁNDOR 2020.

58 Az 1944-ig írt művei: Anyanyelve magyar (1937), Rézpénz (1938), Ezer hold pipacs (1939), Született Moldovában (1940), Keleti magyarok nyomában (1942), Róza leányasszony (1942), Két élet (1943), Hivatalnok Berta (1944). MÉL: Ignácz Rózsa. (https://adtplus.arcanum.hu/hu/view/MagyarEletrajziLexikon_4/?query=Ign\% C3\%A1cz\%20R\%C3\%B3zsa\%201942\&pg=416\&layout=s) [2021.02.16.]

59 Balassa Imre: A Ferenc József-díjas Ignácz Rózsa, aki mindig csak - Ignácz Rózsának készült! Film Színház Irodalom, 1942. június 26.

60 Pusztai-Popovits József: Beszélgetés Ignácz Rózsával, a színésznőből lett írónővel. Pécsi Napló, 1942. október 31. 6.

${ }^{61}$ Erre azért kerülhetett sor, mert 1944 szeptemberében a Lakatos-kormány lépéseket tett a politikai foglyok szabadon bocsátására. MAKKaI 2008.; MMV: Lakatos-kormány. (https://www.arcanum.hu/hu/onlinekiadvanyok/Lexikonok-magyarorszag-a-masodik-vilaghaboruban-lexikon-a-zs-F062E/l-F0B4A/lakatoskormany-F0B4D/) [2021.02.17.]

62 MaKkai 2008.

63 MaKKai 2008. 
A három női életút azt mutatja meg, hogy a konzervatív, keresztyén nőmozgalom tagjai hogyan építették be a saját életükbe a modern, emancipált nő eszményének elemeit. Az élettörténetek a konzervatív feminizmusnak Sárai Szabó Katalin normakövető emancipációval megjelölt fogalmába illeszkedve értelmezhetőek, melynek a lényege, hogy a konzervatív nő „az individuálisnál magasabb értékünek tartott közösségi elvek - Isten, nemzet, társadalom - szolgálata során jut el (...) a nemi szerepek átértelmezéséhez, az önérvényesitéshez és az önmegvalositáshoz, miközben saját társadalmi csoportjának értékrendjét és normáit nem kérdőjelezi meg." ${ }^{44}$ Mindhárom életút egyéni válaszokat mutat meg az emancipációra. Pilder Mária az egyházi pályán találta meg a saját útját. Elhivatottságot érzett a teológiai tanulmányok iránt, $s$ tanárként élte az egyedülálló, az egyházért dolgozó nők független életét. Zsindelyné élete jól mutatja, hogy a normakövetés az élet különböző területein különféleképpen érvényesült. A társadalom nyilvános színterein betöltött (Pántlika, Hunnia Film, Nőszövetség) szerepekben érzékelhettük leginkább a normakövetést. A magánszférában - az anyaszerepben - megjelenik egészen szélsőségesen is az emancipáció hatása. Gyermeke nevelését nagynénjére bízta, és emiatt egész életében bűntudat gyötörte. Ignácz Rózsa független válaszokat adott az emancipációs kihívásokra (unokatestvérével kötött szerelmi házasság, elváltan egy új házasságot kezdeményező volt feleség extrém szerepében látjuk, anyaként pedig inkább viselkedett barátként, mint a klasszikus anyaszerepnek megfelelöen).

\section{Az Új Magyar Asszony rovatai és témái}

Az Országos Református Nőszövetség indulásának körülményeit, a legfőbb céljait és tevékenységét az Új Magyar Asszonyban érhetjük tetten. A havonta egyszer megjelenő lap szerzői a Nőszövetség társadalmi bázisát, a legkülönbözőbb társadalmi rétegű, életkorú református felekezethez tartozó nőket szólították meg azért, hogy mozgósítsák őket az összefogásra, kijelölve a feladatukat az egyházi, a szociális és a művelődés, valamint a gyermeknevelés és háztartásvezetés területein. Ezt igazoljuk abban a táblázatban (Melléklet 1. táblázat), mely áttekintést nyújt az 1944-ben megjelent lapszámok szerzőiről, az 1944ben betöltött társadalmi szerepükről, a cikkeik műfajáról és témáiról.

A vezércikkek a hazáért, az egyházért és nem önmagukért való önzetlen szolgálatra szólították fel a református asszonyokat a Biblia példázataira hivatkozva. E témához kapcsolódtak Zsindelyné Tüdős Klára Házunk tája című jegyzetei, illetve a Szapuló című rovat glosszái (például Szitsátok a lángot).

A Nőszövetség missziós céljait szolgálta Pilder Mária Tükör címủ rovata, melynek középpontjában a Szentírás és annak magyarázata állt. A Kislexikon címü rovat hitoktatás jellegü irásokat közölt a következő témákban: Egyháztagság, Szeretetvendégség, Nők az Újszövetségben, Jézus nemzetségtáblájának asszonyai.

Szíj Rezső Régi Magyar Asszonyok című rovatának egyháztörténeti írásaival, a keresztyén nő ideálképét erősítette a református asszonyok (Bethlen Kata, Bethlen Miklós feleségei, Kun Ilona, Rhédey Júlia) történelmi példáin keresztül. Hasonló funkciót töltött be a Könyvek és a Film/Szinház rovat, melyben a református asszonyok számára íródott filmkri-

64 SÁrAi 2014. 90. 
tikákat, könyvajánlásokat olvashatunk. Ezek között megtalálhatók az újság íróinak művei is, mint például a Marék búza című, Szíj Rezső szerkesztette novelláskötet, Péter János Megbotránkoztató szeretet - tékozló fiú története és Balla Péter Magyar népdal címü könyve.

Zsindelyné Tüdős Klára elkötelezettségét a népművészet, a népi kultúra és a népköltészet iránt több cikk is mutatja. A könyvajánlóban Szirmai Fóris Mária Keresztszemes kézimunkák - Bereg, Szabolcs, Szatmár, Ugocsa megyékben gyüjtött minták címü könyvét ajánlották az újság közönségének. ${ }^{65}$ Mindegyik lapban több oldalon találhatóak keresztszemes minták.

A népi írókat is felkarolta a lap. Az erdélyi író, Balázs Ferenc Rög alatt című könyvéről recenziót olvashatunk a lapban. ${ }^{66}$ Bottyán János $A z$ ábécétól a regényig címü cikkében összegyüjtötte a „paraszt- és a munkásírókat”, kezdve Szabó Pállal. Kiemelte Kassák Lajos mellett Nagy Istvánt, akinek müveiről írja, hogy „Egy-egy kérés, kiáltás minden regénye. Egy társadalmi osztályé. Figyelnünk kell erre a hangra." ${ }^{67}$ Rideg Sándornak novellarészlete jelent meg a lapban. A kortárs költők közül a bihari pásztorcsaládból származó Sinka István, a népi írókhoz tartozó Gulyás Pál és Kodolányi János, valamint a református lelkész ősökkel bíró Szabó Lőrinc és Berze Mária Amália publikált az Új Magyar Asszonyban.

Egy nőknek írt újság divat nélkül nem jelenhetett meg, főleg, ha a híres divattervező, Zsindelyné Tüdős Klára a munkatársai között szerepelt. A Háborús ruhatervek között könnyen elkészíthető, olcsó és praktikus viseleteket ajánlottak a nők és kisgyermekek számára. A téli és nyári munkaruha zsebes köténnyel, hogy „a kulcsot, a pápaszemet ne kelljen folyton keresni" ${ }^{68}$ kifejezetten a háziasszonyok számára készült.

A Receptek című rovatban szereplő ételek a Budapesten egyre fokozódó élelmiszerhiányra mutatnak, mivel fóképp vegetáriánus ételek - burgonya, kelkáposzta, répa, sárgaborsó, valamint tésztafélék - elkészítését ajánlották a háziasszonyoknak, mint például a rakott tarhonyás kelkáposztát, a szűklevű gulyást vagy a hamis húslevest, csurgatott galuskát. Édességként pedig az egy tojással készítendő háborús piskótát javasolták karácsonykor az ünnepi asztalra.

$\mathrm{Az}$ 1944. év mindegyik számában megjelent tudósítás az Országos Református Nőszövetség tevékenységeiről. Így olvashatjuk Tóth Erikának, a Tiszántúli Református Egyházkerület Nőszövetsége titkárának részletes tájékoztatását a debreceni testvércsalád mozgalomról, a bevezetett kartotékrendszerről, mely intézkedésekkel a háború sújtotta, a bombatámadások következtében otthon nélkül maradt családokon kívántak segíteni. A Nőszövetség szociális tevékenységei közé tartozott a hadigondozás, melynek elméleti és gyakorlati ismereteiről is hírt adott Domján János. Az első lapszámban például M. Kovács Piroska diakonissza Otthontalan lányok címmel a tanonclányok fővárosi helyzetéről írt cikket, melyben rávilágított a leánykollégiumok létesítésének szükségességére. A Nőszövetség jótékonysági akcióit segítendő szeretetvendégségek szervezéséhez is praktikus segítséget kívánt nyújtani a lap egy műsortervet tartalmazó Mükedvelés című írással. (Melléklet 1. táblázat)

${ }^{65}$ Új Magyar Asszony 1. (1944):2.

${ }_{6} \quad$ Új Magyar Asszony 1. (1944):3.

67 BotTYÁn János: Az ábécétől a regényig. Új Magyar Asszony 1. (1944):3. 4.

68 Háborús ruhatervek. Új Magyar Asszony 1. (1944):4. 15. 


\section{Összegzés}

Az Országos Református Nőszövetség mozgalmának megindítása azt mutatja, hogy a Magyarországi Református Egyháznak volt stratégiája 1944-ben a változásra. Ravasz László az integráló szerepre megfelelő, a Horthy-korszakban saját erejéből ismertté és elismertté vált, modern, önálló személyiséget, Zsindelyné Tüdős Klárát választotta a mozgalom élére, akinek ismertsége, széles körü kapcsolati hálója mind az egyházban, mind a politikai és a kulturális élet terén azt ígérte, hogy kiszélesíthető az egyház hagyományos társadalmi bázisa, s megerősíthető az egyházhoz való ragaszkodás a női munkán keresztül. A lap szerzői gárdájának és főbb rovatainak tartalmi összegzése is azt bizonyítja, hogy a háború nem gátolta meg a magvetést, és 1944-ben sikerült előkészíteni az ébredés újabb hullámát a Magyar Református Egyházban. 


\section{MeLLÉKLET}

1. táblázat: Az Új Magyar Asszony első évfolyamának összefoglaló táblázata rovat, műfaj, szerző, cím, lapszám szerint.

\begin{tabular}{|c|c|c|c|c|}
\hline $\begin{array}{l}\text { Rovat/ } \\
\text { Múfaj }\end{array}$ & Szerző & $\begin{array}{l}\text { A szerző 1944- } \\
\text { ben betöltött tár- } \\
\text { sadalmi szerepe }\end{array}$ & Cím & $\begin{array}{l}\text { Lapszám } \\
\text { Új Magyar } \\
\text { Asszony }\end{array}$ \\
\hline Vezércikk & $\begin{array}{l}\text { Zsindelyné } \\
\text { Tüdős Klára }\end{array}$ & $\begin{array}{l}\text { Országos Refor- } \\
\text { mátus Nőszövet- } \\
\text { ség elnöke }\end{array}$ & $\begin{array}{c}\text { Asszonyok, } \mathrm{Ti} \\
\text { ne féljetek! }\end{array}$ & $\begin{array}{c}\text { 1944. 1. évf. } \\
\text { 1. sz. 1-2. }\end{array}$ \\
\hline Vezércikk & $\begin{array}{l}\text { Zsindelyné } \\
\text { Tüdős Klára }\end{array}$ & & $\begin{array}{l}\text { Hol vagytok } \\
\text { asszonyok? }\end{array}$ & $\begin{array}{l}\text { 1944. 1. évf. } \\
\text { 2. sz. } 1 .\end{array}$ \\
\hline Vezércikk & Péter János & $\begin{array}{c}\text { A Bethesda } \\
\text { kórház lelkésze } \\
\text { A Református Élet } \\
\text { szerkesztője }\end{array}$ & $\begin{array}{c}\text { Örvendező } \\
\text { szolgálók }\end{array}$ & $\begin{array}{l}\text { 1944. 1. évf. } \\
\text { 3. sz. } 1 \text {. }\end{array}$ \\
\hline Vezércikk & Békési Andor & $\begin{array}{l}\text { Lelkipásztor és } \\
\text { vallásoktató }\end{array}$ & Lélekben együtt & $\begin{array}{l}\text { 1944. 1. évf. } \\
\text { 4. sz. } 1 .\end{array}$ \\
\hline $\begin{array}{l}\text { Vezércikk } \\
\text { Jegyzet }\end{array}$ & Ravasz László & $\begin{array}{c}\text { Református } \\
\text { püspök }\end{array}$ & $\begin{array}{l}\text { Ismeretlen } \\
\text { áldott kezek }\end{array}$ & $\begin{array}{l}\text { 1944. 1. évf. } \\
\text { 1. sz. } 1 .\end{array}$ \\
\hline $\begin{array}{l}\text { Vezércikk } \\
\text { Jegyzet }\end{array}$ & Bottyán János & $\begin{array}{l}\text { Az Új Magyar } \\
\text { Asszony és a } \\
\text { Református Jövő } \\
\text { szerkesztője }\end{array}$ & Így lehet... & $\begin{array}{l}\text { 1944. 1. évf. } \\
\text { 3. sz. } 1 .\end{array}$ \\
\hline $\begin{array}{l}\text { Vezércikk } \\
\text { Jegyzet }\end{array}$ & $\begin{array}{l}\text { Kempis } \\
\text { Tamás }\end{array}$ & $\begin{array}{l}\text { Késő középkori } \\
\text { németalföldi pap, } \\
\text { író, teológus, a } \\
\text { devotio moderna } \\
\text { képviselője }\end{array}$ & $\begin{array}{c}\text { Karácsonyfa } \\
\text { helyett }\end{array}$ & $\begin{array}{c}\text { 1944. 1. évf. } \\
\text { 4. sz. } 1 .\end{array}$ \\
\hline Belső cikk & $\begin{array}{l}\text { Makkai } \\
\text { Sándor }\end{array}$ & $\begin{array}{c}\text { Debreceni } \\
\text { Teológia tanára }\end{array}$ & $\begin{array}{l}\text { Mi a Reformá- } \\
\text { tus Nőszövetség? }\end{array}$ & $\begin{array}{c}\text { 1944. 1. évf. } \\
\text { 1. sz. 5-6. }\end{array}$ \\
\hline $\begin{array}{l}\text { Szapuló } \\
\text { glossza }\end{array}$ & Kátai István & Humorista & Divat és erkölcs & $\begin{array}{c}\text { 1944. 1. évf. } \\
\text { 1. sz. } 2 .\end{array}$ \\
\hline Szapuló & Kátai István & & A nyelv & \\
\hline
\end{tabular}




\begin{tabular}{|c|c|c|c|c|}
\hline Szapuló & Szerző nélkül & & $\begin{array}{l}\text { Szítsátok a } \\
\text { lángot } \\
\text { (Családi tűz- } \\
\text { hely) }\end{array}$ & $\begin{array}{l}\text { 1944. 1. évf. } \\
\text { 3. sz. } 2 .\end{array}$ \\
\hline $\begin{array}{l}\text { Szapuló } \\
\text { Nyílt levél a } \\
\text { szerkesztő- } \\
\text { höz, ironikus } \\
\text { hangvételű }\end{array}$ & Szerző nélkül & & Kismosás & $\begin{array}{l}\text { 1944. 1. évf. } \\
\text { 4. sz. } 2 .\end{array}$ \\
\hline Jegyzet & Ignácz Rózsa & Író & Az olvasásról & $\begin{array}{c}\text { 1944. 1. évf. } \\
\text { 1. sz. } 3 .\end{array}$ \\
\hline Jegyzet & Ignácz Rózsa & & A gyermek olvas & $\begin{array}{l}\text { 1944. 1. évf. } \\
\text { 3. sz. } 3 \text {. }\end{array}$ \\
\hline Jegyzet & Ignácz Rózsa & & $\begin{array}{l}\text { Menekülés a } \\
\text { betủhöz }\end{array}$ & $\begin{array}{l}\text { 1944. 1. évf. } \\
\text { 4. sz. 3-4. }\end{array}$ \\
\hline Bírálat & Bottyán János & & $\begin{array}{l}\text { Az ábécétől a } \\
\text { regényig }\end{array}$ & $\begin{array}{l}\text { 1944. 1. évf. } \\
\text { 3. sz. } 4 .\end{array}$ \\
\hline $\begin{array}{c}\text { István deák } \\
\text { tréfája Tárca } \\
\text { (tollrajz) }\end{array}$ & Kátai István & Humorista & Rozi néni & $\begin{array}{l}\text { 1944. 1. évf. } \\
\text { 1. sz. } 4 .\end{array}$ \\
\hline $\begin{array}{c}\text { István deák } \\
\text { tréfája Tárca } \\
\text { (tollrajz) }\end{array}$ & Kátai István & & $\begin{array}{c}\text { Lajos bácsi útra } \\
\text { kél }\end{array}$ & $\begin{array}{l}\text { 1944. 1. évf. } \\
\text { 2. sz. } 7 .\end{array}$ \\
\hline Jegyzet & $\begin{array}{l}\text { Dr. Kiss } \\
\text { Mihály }\end{array}$ & $\begin{array}{l}\text { Az óbudai Szent } \\
\text { Alajos Szalézi } \\
\text { Rendház vezetője, } \\
\text { menekült lengyel } \\
\text { szalézi atyákat, } \\
\text { majd a nyilaske- } \\
\text { resztes uralom } \\
\text { alatt zsidókat } \\
\text { fogadott be. }\end{array}$ & $\begin{array}{c}\text { A csontok } \\
\text { bizonyságtétele } \\
\text { a női hivatásról } \\
\text { Artemisztől } \\
\text { korunk fiús } \\
\text { asszonyáig }\end{array}$ & $\begin{array}{l}\text { 1944. 1. évf. } \\
\text { 1. sz. } 7 .\end{array}$ \\
\hline
\end{tabular}




\begin{tabular}{|c|c|c|c|c|}
\hline Recenzió & $\begin{array}{c}\text { Kovács István } \\
\text { dr. }\end{array}$ & $\begin{array}{l}\text { Szentmártonká- } \\
\text { tán lelkipásztor } \\
\text { A Magyar Út és a } \\
\text { Keresztyén Család } \\
\text { munkatársa }\end{array}$ & $\begin{array}{c}\text { Egy porrá } \\
\text { omlott világ } \\
\text { üzen } \\
\text { Mit mond } \\
\text { a tudós a } \\
\text { honfoglaláskori } \\
\text { magyar asszo- } \\
\text { nyok életéről? }\end{array}$ & $\begin{array}{l}\text { 1944. 1. évf. } \\
\text { 2. sz. 5-6. }\end{array}$ \\
\hline Jegyzet & $\begin{array}{l}\text { Szolárcsik } \\
\text { Sándor }\end{array}$ & Író & Dolgozó nő & $\begin{array}{l}\text { 1944. 1. évf. } \\
\text { 2. sz. 3-4. }\end{array}$ \\
\hline Novella & Rideg Sándor & $\begin{array}{l}\text { Író. A munkás- } \\
\text { mozgalomhoz hű. } \\
\text { 1944-ig rendőri } \\
\text { felügyelet alatt } \\
\text { állt, koncentrációs } \\
\text { táborba hurcol- } \\
\text { ták. Az Indul a } \\
\text { bakterház szerzője } \\
\text { (1943), Zilahi } \\
\text { Lajos támogatta a } \\
\text { megjelenését. }\end{array}$ & $\begin{array}{c}\text { A csodálatos } \\
\text { gépezet... }\end{array}$ & $\begin{array}{l}\text { 1944. } 1 \text { évf. } \\
\text { 3. sz. 7-8. }\end{array}$ \\
\hline $\begin{array}{l}\text { Régi Magyar } \\
\text { Asszonyok } \\
\text { Ismeretter- } \\
\text { jesztő cikk }\end{array}$ & Szíj Rezső & $\begin{array}{c}\text { Sárvárott } \\
\text { református lelkész, } \\
\text { művelődés- és } \\
\text { irodalomtörténész, } \\
\text { író }\end{array}$ & $\begin{array}{c}\text { Árva } \\
\text { Bethlen Kata } \\
\text { önéletírásából }\end{array}$ & $\begin{array}{l}\text { 1944. 1. évf. } \\
\text { 1. sz. 8-10. }\end{array}$ \\
\hline $\begin{array}{l}\text { Régi Magyar } \\
\text { Asszonyok } \\
\text { Ismeretter- } \\
\text { jesztő cikk }\end{array}$ & Szíj Rezső & & $\begin{array}{c}\text { Egy férfi két } \\
\text { asszonyról } \\
\text { Bethlen Miklós } \\
\text { feleségei (Kun } \\
\text { Ilona, Rhédei } \\
\text { Júlia) }\end{array}$ & $\begin{array}{l}\text { 1944. } 1 \text { évf. } \\
\text { 3. sz. 5-6. }\end{array}$ \\
\hline
\end{tabular}




\begin{tabular}{|c|c|c|c|c|}
\hline $\begin{array}{l}\text { Régi Magyar } \\
\text { Asszonyok } \\
\text { Ismeretter- } \\
\text { jesztő cikk }\end{array}$ & Szíj Rezső & & $\begin{array}{l}\text { Készülődés az } \\
\text { asszonyi életre }\end{array}$ & $\begin{array}{c}\text { 1944. 1. évf. } \\
\text { 4. sz. 5-6. }\end{array}$ \\
\hline $\begin{array}{c}\text { Tükör } \\
\text { Bibliamagya- } \\
\text { rázat }\end{array}$ & Pilder Mária & $\begin{array}{l}\text { Országos Refor- } \\
\text { mátus Nőszövet- } \\
\text { ség titkára }\end{array}$ & $\begin{array}{l}\text { Megvásárolt } \\
\text { rabszolgák }\end{array}$ & $\begin{array}{l}\text { 1944. 1. évf. } \\
\text { 1. sz. } 10 .\end{array}$ \\
\hline $\begin{array}{c}\text { Tükör } \\
\text { Bibliamagya- } \\
\text { rázat }\end{array}$ & Pilder Mária & & Szentek & $\begin{array}{c}\text { 1944. 1. évf. } \\
\text { 2. sz. } 6 .\end{array}$ \\
\hline $\begin{array}{c}\text { Tükör } \\
\text { Bibliamagya- } \\
\text { rázat }\end{array}$ & Pilder Mária & & $\begin{array}{l}\text { Kegyelem, bé- } \\
\text { kesség, szeretet }\end{array}$ & $\begin{array}{l}\text { 1944. 1. évf. } \\
\text { 3. sz. }\end{array}$ \\
\hline $\begin{array}{c}\text { Tükör } \\
\text { Bibliamagya- } \\
\text { rázat }\end{array}$ & Pilder Mária & & A szeretet titka & $\begin{array}{l}\text { 1944. 1. évf. } \\
\text { 4. sz. }\end{array}$ \\
\hline Tárca & Pilder Mária & & $\begin{array}{l}\text { Mit szól hozzá } \\
\text { Pál apostol? }\end{array}$ & $\begin{array}{c}\text { 1944. 1. évf. } \\
\text { 4. sz. } 7 .\end{array}$ \\
\hline $\begin{array}{l}\text { Lányok } \\
\text { Lapja } \\
\text { Tudósítás }\end{array}$ & $\begin{array}{l}\text { M. Kovács } \\
\text { Piroska }\end{array}$ & Diakonissza & $\begin{array}{l}\text { Otthontalan } \\
\text { lányok }\end{array}$ & $\begin{array}{l}\text { 1944. 1. évf. } \\
\text { 1. sz. } 11 .\end{array}$ \\
\hline $\begin{array}{l}\text { (Tudósítás az } \\
\text { ORN tevé- } \\
\text { kenységeiről) }\end{array}$ & Tóth Erika & $\begin{array}{l}\text { Tiszántúli Refor- } \\
\text { mátus Nőszövet- } \\
\text { ség vezetője }\end{array}$ & $\begin{array}{c}\text { A debreceni } \\
\text { testvér-családok }\end{array}$ & $\begin{array}{c}\text { 1944. 1. évf. } \\
\text { 1. sz. } 12 .\end{array}$ \\
\hline $\begin{array}{l}\text { (Tudósítás az } \\
\text { ORN tevé- } \\
\text { kenységeiről) }\end{array}$ & Szerző nélkül & & $\begin{array}{c}\text { Menekültek } \\
\text { között }\end{array}$ & $\begin{array}{c}\text { 1944. 1. évf. } \\
\text { 2. sz. } 8 .\end{array}$ \\
\hline $\begin{array}{l}\text { (Tudósítás az } \\
\text { ORN tevé- } \\
\text { kenységeiről) }\end{array}$ & Szerző nélkül & & $\begin{array}{c}\text { Amit az asszony } \\
\text { akar }\end{array}$ & $\begin{array}{l}\text { 1944. } 1 \text { évf. } \\
\text { 3. sz. }\end{array}$ \\
\hline
\end{tabular}




\begin{tabular}{|c|c|c|c|c|}
\hline Tudósítás & $\begin{array}{c}\text { Domján János } \\
\text { dr. }\end{array}$ & $\begin{array}{l}\text { Budapest Kül- } \\
\text { ső Józsefváros } \\
\text { lelkipásztora. } \\
\text { Énekszerzo, szoci- } \\
\text { ológiai és egyház- } \\
\text { társadalmi írások } \\
\text { szerzője }\end{array}$ & Hadigondozó & $\begin{array}{l}\text { 1944. 1. évf. } \\
\text { 1. sz. }\end{array}$ \\
\hline Müsorterv & Szerző nélkül & & Mükedvelés & $\begin{array}{l}\text { 1944. 1. évf. } \\
\text { 1. sz.14. }\end{array}$ \\
\hline $\begin{array}{c}\text { Házunk tája } \\
\text { Jegyzet }\end{array}$ & $\begin{array}{l}\text { Zsindelyné } \\
\text { Tüdős Klára }\end{array}$ & & $\begin{array}{l}\text { Téma: Női } \\
\text { szerepekről, az } \\
\text { úrhatnámságról }\end{array}$ & $\begin{array}{l}\text { 1944. 1. évf. } \\
\text { 2. sz. }\end{array}$ \\
\hline $\begin{array}{c}\text { Házunk tája } \\
\text { Jegyzet }\end{array}$ & $\begin{array}{l}\text { Zsindelyné } \\
\text { Tüdős Klára }\end{array}$ & & „Megváltozott” & $\begin{array}{l}\text { 1944. 1. évf. } \\
\text { 3. sz. }\end{array}$ \\
\hline $\begin{array}{c}\text { Házunk tája } \\
\text { Jegyzet }\end{array}$ & $\begin{array}{l}\text { Zsindelyné } \\
\text { Tüdős Klára }\end{array}$ & & $\begin{array}{l}\text { Téma: az aján- } \\
\text { dékozás }\end{array}$ & $\begin{array}{l}\text { 1944. 1. évf. } \\
\text { 4. sz. }\end{array}$ \\
\hline $\begin{array}{l}\text { Szerkesztői } \\
\text { üzenetek }\end{array}$ & Szerző nélkül & & & $\begin{array}{l}\text { 1944. } 1 . \\
\text { évf. } 2 . \text { sz.- } \\
\text { tól minden } \\
\text { számban }\end{array}$ \\
\hline $\begin{array}{c}\text { Vidámsarok } \\
\text { Karcolat }\end{array}$ & Szerző nélkül & & $\begin{array}{c}\text { Mire jó a nőszö- } \\
\text { vetség? }\end{array}$ & $\begin{array}{l}\text { 1944. 1. évf. } \\
\text { 2. sz. } 9 .\end{array}$ \\
\hline
\end{tabular}




\begin{tabular}{|c|c|c|c|}
\hline $\begin{array}{c}\text { Könyvek } \\
\text { Ismertetés/ } \\
\text { ajánlás }\end{array}$ & Szerző nélkül & $\begin{array}{l}\text { Marék búza } \\
\text { - Szíj Rezső } \\
\text { szerkesztette } \\
\text { novelláskötet } \\
\text { kortárs írók } 16 \\
\text { elbeszélésével. } \\
\text { Vásárhelyi János: } \\
\text { A református nö } \\
\text { élete - erdélyi } \\
\text { nőszövetségről. } \\
\text { Péter János: } \\
\text { Megbotránkoz- } \\
\text { tató szeretet-a } \\
\text { tékozló fiú tör- } \\
\text { ténete. }\end{array}$ & $\begin{array}{l}\text { 1944. 1. évf. } \\
\text { 1. sz. }\end{array}$ \\
\hline $\begin{array}{c}\text { Könyvek } \\
\text { Ismertetés/ } \\
\text { ajánlás }\end{array}$ & Szerző nélkül & $\begin{array}{l}\text { Szirmai Fóris } \\
\text { Mária: Kereszt- } \\
\text { szemes kézimun- } \\
\text { kák } \\
\text { Kocsi Csergő } \\
\text { Bálint: Magyar } \\
\text { vértanúk nyomá- } \\
\text { ban } \\
\text { Balla Péter: } A \\
\text { magyar népdal } \\
\text { kistükre }\end{array}$ & $\begin{array}{l}\text { 1944. 1. évf. } \\
\text { 2. sz. }\end{array}$ \\
\hline Recenzió & Szerző nélkül & $\begin{array}{c}\text { Rög alatt } \\
\text { Balázs Ferenc } \\
\text { könyve }\end{array}$ & $\begin{array}{l}\text { 1944. } 1 \text { évf. } \\
\text { 3. sz. }\end{array}$ \\
\hline $\begin{array}{c}\text { Könyvek } \\
\text { Ismertetés/ } \\
\text { ajánlás }\end{array}$ & Szerző nélkül & $\begin{array}{l}\text { Egy indián lány } \\
\text { szerelmeslevele } \\
\text { Várkonyi Nán- } \\
\text { dor: } A z \text { irás } \\
\text { története c. } \\
\text { könyvröl }\end{array}$ & $\begin{array}{l}\text { 1944. 1. évf. } \\
\text { 4. sz. }\end{array}$ \\
\hline
\end{tabular}




\begin{tabular}{|c|c|c|c|c|}
\hline $\begin{array}{c}\text { Film } \\
\text { Kritika }\end{array}$ & $\begin{array}{c}\text { Fekete Lajos } \\
\text { dr. }\end{array}$ & $\begin{array}{l}\text { színész, operett- } \\
\text { színész, rendező }\end{array}$ & $\begin{array}{l}\text { Asszony a lejtön } \\
\text { és Az első c. } \\
\text { filmek kritikája }\end{array}$ & $\begin{array}{l}\text { 1944. 1. évf. } \\
\text { 2. sz. } 9 .\end{array}$ \\
\hline $\begin{array}{c}\text { Film/Színház } \\
\text { Kritika }\end{array}$ & $\begin{array}{c}\text { Fekete Lajos } \\
\text { dr. }\end{array}$ & & $\begin{array}{l}\text { A Nagyúr c. } \\
\text { Nemzeti Színház } \\
\text { darabjának és az } \\
\text { Idegen utakon c. } \\
\text { film kritikája }\end{array}$ & $\begin{array}{l}\text { 1944. 1. évf. } \\
\text { 4. sz. }\end{array}$ \\
\hline $\begin{array}{l}\text { Kislexikon/ } \\
\text { Lexikon } \\
\text { Cikk }\end{array}$ & Szerző nélkül & & $\begin{array}{l}\text { Egyháztagság } \\
\text { Szeretetvendég- } \\
\text { ség }\end{array}$ & $\begin{array}{l}\text { 1944. 1. évf. } \\
\text { 2. sz. } 9 .\end{array}$ \\
\hline $\begin{array}{c}\text { Kislexikon } \\
\text { Cikk }\end{array}$ & Szerző nélkül & & $\begin{array}{l}\text { Nők az Újszö- } \\
\text { vetségben }\end{array}$ & $\begin{array}{l}\text { 1944. 1. évf. } \\
\text { 3. sz. }\end{array}$ \\
\hline $\begin{array}{c}\text { Kislexikon } \\
\text { Cikk }\end{array}$ & Szerző nélkül & & $\begin{array}{l}\text { Jézus nemzet- } \\
\text { ségtáblájának } \\
\text { asszonyai }\end{array}$ & $\begin{array}{l}\text { 1944. 1. évf. } \\
\text { 4. sz. }\end{array}$ \\
\hline Receptek & Szerző nélkül & & $\begin{array}{c}\text { Hústalan ételek } \\
\text { Receptek }\end{array}$ & $\begin{array}{l}\text { 1944. 1. évf. } \\
\text { 2. sz.-tól min- } \\
\text { den számban }\end{array}$ \\
\hline $\begin{array}{c}\text { Háborús } \\
\text { ruhatervek }\end{array}$ & Szerző nélkül & & & $\begin{array}{l}\text { 1944. 1. évf. } \\
\text { 4. sz. }\end{array}$ \\
\hline Kézimunka & Szerző nélkül & & $\begin{array}{c}\text { Keresztszemes } \\
\text { minták }\end{array}$ & $\begin{array}{c}\text { Minden szám } \\
\text { ban }\end{array}$ \\
\hline $\begin{array}{l}\text { Egyházi éne- } \\
\text { kek } \\
\text { Kotta szöveg- } \\
\text { gel }\end{array}$ & Szerző nélkül & & $\begin{array}{c}\text { Újszövetségi } \\
\text { lelki ének } \\
\text { Krisztus a király } \\
\text { Nekünk születék } \\
\text { mennyei király } \\
\text { Karácsonyi ének }\end{array}$ & $\begin{array}{l}\text { 1944. 1. évf. } \\
\text { 2. sz. } 6 . \\
\text { 1944. 1. évf. } \\
\text { 3. sz. } \\
\text { 1944. 1. évf. } \\
\text { 4. sz. 4., } 6 .\end{array}$ \\
\hline
\end{tabular}




\begin{tabular}{|c|c|c|c|}
\hline Versek & $\begin{array}{l}\text { Szőllősy } \\
\text { István } \\
\text { Tompa } \\
\text { Mihály }\end{array}$ & $\begin{array}{l}\text { A gondolat } \\
\text { Tornácomon }\end{array}$ & $\begin{array}{l}\text { 1944. 1. évf. } \\
\text { 1. sz. 2., } 6 .\end{array}$ \\
\hline Versek & $\begin{array}{l}\text { Szabó Lőrinc } \\
\text { Petőfi Sándor } \\
\text { Szabó Lőrinc } \\
\text { Gulyás Pál }\end{array}$ & $\begin{array}{c}\text { Egy pohár víz } \\
\text { Honfidal } \\
\text { Piszkosságok } \\
\text { Örizd a lámpát }\end{array}$ & $\begin{array}{l}\text { 1944. 1. évf. } \\
\text { 2. sz. 1.,2.,4. }\end{array}$ \\
\hline Versek & $\begin{array}{l}\text { Sinka István } \\
\text { Lope de Vega } \\
\text { (Szabó Lőrinc } \\
\text { fordítása) } \\
\text { Sinka István } \\
\text { Oláh Gábor }\end{array}$ & $\begin{array}{l}\text { Alvó körözsök } \\
\text { Házi boldogság } \\
\text { Fügedi halálára } \\
\text { Dolgozatjavítás }\end{array}$ & $\begin{array}{c}\text { 1944. 1. évf. } \\
\text { 3. sz. 1., 2., } \\
\text { 4., } 6 .\end{array}$ \\
\hline Versek & $\begin{array}{c}\text { Gellért Sán- } \\
\text { dor } \\
\text { Eino Leino } \\
\text { (Fordító: Ko- } \\
\text { dolányi János) } \\
\text { Csokonai Vi- } \\
\text { téz Mihály }\end{array}$ & $\begin{array}{c}\text { Egy régi } \\
\text { karácsony } \\
\text { Békétlen ember } \\
\text { könyörgése } \\
\text { A szabadsághoz }\end{array}$ & $\begin{array}{l}\text { 1944. } 1 \text { évf. } \\
\text { 4. sz.1., 2., } 7 .\end{array}$ \\
\hline
\end{tabular}

Szerk.: Ács 2021. Forrás: Új Magyar Asszony 1944. 1. évfolyam 1-4. szám.

\section{KÉPJEGYZÉK}

1. kép

Gáborjáni Szabó Kálmán fametszete, a lap egyetlen illusztrációja. Forrás: Új Magyar Asszony 1. (1944):2. 1. 


\section{LEVÉLTÁRI FORRÁSOK}

BREL

B.12.c.

ZsL

80. fond

48. fond
Baranyai Református Egyházmegye Levéltára

B. Személyek, családok, egyesületek, alapítványok iratai. 12. Regnum Christianum Egyesület iratai. c. Pécsi Református Egyházközség Nőszövetségének iratai.

Zsinati Levéltár

Bottyán János adattára

Pilder Mária iratai 1884-1956

\section{SAJTÓfORRÁSOK}

Demokrácia, 1946

Dunántúli Protestáns Lap, 1944

Élet, 1938

Fényszóró, 1945

Film Színház Irodalom, 1942

Magyarország, 1937

Muskátli, 1938

Népszava, 2001

Pécsi Napló, 1942

Új Magyar Asszony, 1944

Új Magyarság, 1938

Valóság, 1983

\section{IRODALOM}

Ács 2015

Ács Marianna: A belmisszió hatása a pécsi református gyülekezeti életre Nyáry Pál szolgálata idején (1903-1952). 2015. (http:// www.baranyaireformatusleveltar.hu/publikaciok) [2021.02.14.]

Bagyinszky 2011 Bagyinszky Marianna: Pesti „magyaros” divat a két világháború között. Honismeret (2011):3. 61-63. (http://epa. oszk.hu/03000/03018/00225/pdf/EPA03018_honismeret_2011_03_061-063.pdf) [2021.02.17.] 
CseH -

MÉsZÁros 2006

Czeferner 2020

DeZsÉNYI et al 1956

DIZSERI 1994

F. Dózsa 1998

GÉRA 2006

Gergely 1995

GYÁNi 2006

KÉRI 2019

KÉRI 2013

KIss 2006

KósA 2006

LADÁNYI 1996
Csen Gizella - MészÁros Borbála: A Budapest mai területén megjelenő református és közös protestáns időszaki sajtó jegyzéke (1818-2004). In: Reformátusok Budapesten 2. Tanulmányok a magyar fóváros reformátusságáról. Szerk. KósA László. Budapest, 2006. 1231-1300.

Czeferner Dóra: Polgári liberális, feminista nöszervezetek és sajtójuk az Osztrák-Magyar Monarchiában (1907-1918). Doktori disszertáció. Pécs, 2020. (https://doktori.hu/index.php?menuid =193\&lang=HU\&vid=21777) [2021.03.23.]

A magyar sajtó bibliográfiája 1945-1954. Szerk. Dezsényi Béla - Falvy Zoltán - FejÉr Judit. Budapest, 1956.

Zsindelyné Tüdös Klára: Életrajz - dokumentumokban, 18951980. Szerk. Dizseri Eszter. Budapest, 1994.

F. Dózsa Katalin: A magyar ruha feltámadása. Népviselet és napi divat a harmincas években. Rubicon 81. (1998):7. 48-50.

GÉrA Eleonóra Erzsébet: Református karitativ intézmények a magyar fóvárosban 1850-1952. Doktori disszertáció. Budapest, 2006. (http://doktori.btk.elte.hu/hist/gera/diss.pdf) [2021.02.19.]

Gergely Jenő: Az egyházak Magyarországon a Horthy-korszakban. Iskolakultúra 5. (1995):1-2. 26-31.

GYÁNI Gábor: Sajtótörténet a társadalomtörténész szempontjából. Médiakutató 7. (2006):1. 57-64.

KÉRI Katalin: Tendenciák és eredmények a nőnevelés-történet kutatásában. In: „Asszonyoknak igen sokat kell tudni...” Új kutatások a nönevelés történetéröl. Szerk. Ács Marianna et al. Pécs, 2019. 17-31.

KérI Katalin: Tendenciák és eredmények a nönevelés-történet nemzetközi kutatásában. Neveléstörténet és nönevelés-történet. (http://nevelestudomany.elte.hu/downloads/2013/ nevelestudomany_2013_3_22-39.pdf) [2021.03.25.]

KIss Réka: Református ébredés Budapesten. In: Reformátusok Budapesten 2. Tanulmányok a magyar fóváros reformátusságáról. Szerk. Kósa László. Budapest, 2006. 1343-1367.

KósA László: Zsindelyné Tüdős Klára és az Országos Református Nőszövetség. In: Reformátusok Budapesten 1. Tanulmányok a magyar fóváros reformátusságáról. Szerk. KósA László. Budapest, 2006. 741-755.

LADÁNYI Sándor: A II. világháború éveiben (1941-1944). In: Magyarország a XX. században. II. kötet. Szerk. Kollega TARsoly István. Szekszárd, 1997. 371-372. 
MAKKAI 1938

MAKKAI 2008

MÉL

MiKLós 2007

MMV

PÁlmai 2012

RÉBAY 2009

RÉBAY 2011

RÉBAY 2019

RMIL

SÁNDOR 2020
MakkaI Sándor: Az egyház missziói munkája. Budapest, 1938. MaKкAI Ádám: Ignácz Rózsa emlékezete születése 100. és halála 30. évfordulóján (Egy bevallottan "elfogult" személyes és irodalmi leszármazott tollából). (https://adam.makkai.org/ignacz-rozsa/ ignacz-rozsa-emlekezete/) [2021.03.23.]

Magyar Életrajzi Lexikon [online]. (https://www.arcanum.hu/ en/online-kiadvanyok/Lexikonok-magyar-eletrajzi-lexikon7428D/) [2021.02.16.]

MikLós Péter: Konfliktus és szolidaritás. Szempontok Horthy Miklós és a katolikus egyház kapcsolatának értelmezéséhez. Egyháztörténeti Szemle 8. (2007):2. 205-212.

Magyarország a második világháborúban. Lexikon A-ZS. (https://www.arcanum.hu/hu/online-kiadvanyok/Lexikonokmagyarorszag-a-masodik-vilaghaboruban-lexikon-a-zs-F062E/) [2021.02.17.]

PÁlmai Dóra: Együtt vagy egymás mellett? - A felsöoktatás koedukációja a XIX. században. (https://regi.tankonyvtar.hu/hu/tartalom/tamop422b/2010-0029_kotet_16_259/259_10_10.html) [2021.03.25.]

PApp - Sipos 2017 Papp Barbara - Sipos Balázs: Modern, diplomás nö a Horthy-korban. Budapest, 2017.

Ravasz László: Elöszó. Országos Református Nöszövetség munkaterve. Szerk. Zsindely FerencNé Tüdős Klára - Ravasz László. Budapest, 1944.

RÉBAY Magdolna: Leány-középiskolák Magyarországon és a német nyelvü országokban: a jogi szabályozás az 1870-es évektöl 1945-ig. Budapest, 2009.

RÉBAY Magdolna: Református közoktatás a fövárosban a kezdetektöl 1952-ig: kitekintéssel az illetékes egyházmegyék és a Dunamelléki Református Egyházkerület oktatási politikájára. Debrecen, 2011.

RÉBAY Magdolna: Középiskolai koedukáció - pró és kontra (1891-1944). In: „Asszonyoknak igen sokat kell tudni... ” Új kutatások a nönevelés történetéröl. Szerk. Ács Marianna et al. Pécs, 2019. 31-49.

Berde Mária. Romániai Magyar Irodalmi Lexikon. (https://lexikon.kriterion.ro/szavak/340/) [2021.02.19.]

SÁNDor Zsuzsanna: Élni, csak élni szeretnék - Ignácz Rózsa, az elfelejtett irónö. (https://fidelio.hu/szinhaz/elni-csak-elniszeretnek-ignacz-rozsa-az-elfelejtett-irono-157750.html) [2021.02.14.] 
SÁrAi 2002

SÁRAI 2009

SÁrAI 2011

SÁrAi 2014

Sipos 2014

SvÉD 2013

TOMPA

ZSINDELYNÉ 1998
SÁrai Szabó Katalin: Református lelkésznék a két világháború közötti református lapokban. In: Ráday gyüjtemény Évkönyve X. Szerk. Petrőczi Éva. Budapest, 2002. 175-186.

SÁrai Szabó Katalin: „Családi élet őrizői, magyar református anyák, asszonyok...” Nők a két világháború közötti református egyházi sajtóban. Médiakutató 10. (2009):1. 83-94.

SÁrai Szabó Katalin: A református nö a 19. század végétöl az 1930-as évekig. A belmissziói mozgalom hatása a nök egyházi müködésére. Doktori disszertáció. Budapest, 2011. (http://doktori. btk.elte.hu/hist/saraiszabokatalin/diss.pdf) [2021.02.19.]

SÁrai Szabó Katalin: Normakövető női emancipáció. A konzervatív nőmozgalom Magyarországon a 19. század végén, 20. század elején. Replika 85-86. (2014):1-2. 85-106.

Sipos Balázs: Modern amerikai lány, új nő és magyar asszony a Horthy-korban. Egy nőtörténeti szempontú médiatörténeti vizsgálat. Századok 148. (2014):1. 3-34.

SvÉD László: Az 1942, 1943-as évek balatonszárszói találkozóinak ifjúságtörténeti előzményei. Múltunk 58. (2013):1. 101-147.

Tompa Mihály összes verse (https://www.arcanum.hu/hu/onlinekiadvanyok/Verstar-verstar-otven-kolto-osszes-verse-2/tompamihaly-9406/) [2021.04.15.]

Zsındelyné Tüdős Klára: Csizma az asztalon. Budapest, 1998.

\section{HANGFELVÉTEL}

Magyaros divat. Zsindely Ferencné Tüdős Klára előadása az Országos Iparművészeti Társulat női ruhabemutatóján. MFI: Nagy L., Zsabka, Marton. (https://filmhiradokonline. hu/watch.php?id=3489) [2021.02.16.] 


\section{Circumstances of the Start of the National Calvinist Women's Association (1943-1944) \\ by Marianna Ács \\ (Summary)}

In September 1944, József Pongrácz (theology teacher and the editor of the Transdanubian Protestant Journal) promoted the new journal of the National Calvinist Women's Association (titled: The New Hungarian Woman): „[it] intends to knock on the Hungarian Calvinist homes every month so that Hungarian women can draw strength in the struggles that await them (...). [T] his journal will be a link between millions of Calvinist women, an awakening conscience for the dormant. With the journal, our weaking power multiples."

The study aims to provide a press analysis from a socio-historical perspective that aims to shed light on the social context of 1944, in which the four issues were published. It also wants to answer the question of how the monthly periodicals mediated the goals of the National Calvinist Women's Association and the Hungarian Calvinist Church at a historical turning point. We present these research goals with a focus on the life and social network of the president of the National Calvinist Women's Association, Klára Zsindelyné Tüdős.

Our aim is to draw attention to the editorial staff and to the connection points that are related to the objectives of the paper and the National Calvinist Women's Association. The subject of the study is the biographical elements of the leading female authors - Klára Zsindelyné Tüdős, Mária Pilder, Rózsa Ignácz - covering the events they experienced in the autumn of 1944, at the time of their work in the paper. The study is conducted with qualitative content analysis based on articles in the journals, author's biographies and memoirs. The study is an initial step in exploring the activities of the National Calvinist Women's Association and in analyzing the The New Hungarian Woman. It adds to the slice of history of the Calvinist press written for female readers. 